\title{
COMBINING ABILITY OF NINE WHITE MAIZE INBRED LINES FOR YIELD AND SOME AGRONOMIC TRAITS
}

\author{
A.K. Mostafa and M.A.A. Mostafa \\ Maize Res. Dep., Field Crops Res. Institute, ARC
}

Received: Apr. 30,2017

Accepted: Aug. 3, 2017

\begin{abstract}
Combining ability analysis was conducted for grain yield, yield components and some agronomic traits, i.e. days to $50 \%$ silking, plant and ear heights in a half- diallel cross system involving nine white maize inbred lines. The results indicated that variance due to both general (GCA) and (SCA) specific combining ability was highly significant for all studied traits, indicating the importance of both additive and non-additive gene effects in the inheritance of studied traits. The magnitude of the ratio of general to specific combining ability variance $\left(\delta^{2}\right.$ $G C A, \delta^{2} S C A$ ) indicated that the additive was more important than non-additive gene action in the inheritance of studied traits. Estimation of GCA effects of parents revealed that, parent $P_{2}$, $P_{3}$ and $P_{9}$ were the best combiner for grain yield and some of its components, while the best general combiner for earliness were $P_{1}, P_{7}$ and $P_{8}$. The best crosses $P_{1} X P_{9}$ and $P_{3} X P_{9}$ had the positive SCA effects and the highest performance for grain yield. Such suppression inbred lines and crosses can be utilized in the national hybrid breeding program to produce high yielding hybrids.
\end{abstract}

Key words: White maize, GCA, SCA, Additive, Non-additive variance.

\section{INTRODUCTION}

Maize (Zea mays L.) is one of the most important cereal crops in Egypt. It ranks the third among cereal crops, after wheat and rice. Maize is used as food, feed, and fodder. It also has several industrial uses such as oil extraction, starch, gluten, alcohol, glucose and ethanol production and many more products.

Diallel crosses in maize were developed by Sprague and Tatum (1942) who partitioned the variation among $F_{1}$ crosses resulting from inbred lines to general (G.C.A.) and specific (S.C.A.) combining ability. Matzinger et al. (1959) revealed that the G.C.A. variance is a function of additive variance, while S.C.A. variance is a function of the non-additive variance. Griffing (1956) gave a complete analysis of diallel crosses for fixed and random set of parents. ElShamarka (1995), Abd El-Aty and Katta (2002) and Ibrahim et al. (2010) reported that specific combining ability effects were much more important in the inheritance of grain yield and its components. Meanwhile, Beck et al. (1991), El-Hosary et al. (1999), Abd El-Moula (2005), Derera et al. (2008), Vivek et al. (2010) and Sibiya et al. (2011) reported that general combining ability was more important in determining yield and other characters.

The main objectives of this study were: 1) to estimates general and specific combining ability for some quantitative characters in a set of nine inbred lines and 2) to identify the best promising crosses.

\section{MATERIALS AND METHODS}

Nine white maize inbred lines (Zea maize L.) were isolated at Mallawy Agriculture Research Station. National Maize Research Program.

In 2014 season, inbreeds were crossed at Mallawy Agriculture Research Station, a half diallel set of crosses were made among the nine parents giving a total of $36 \mathrm{~F} 1$ crosses. 
In 2015 season, the resultant $36 \mathrm{~F}_{1}$ crosses along with two commercial single cross hybrids as checks i.e, SC 10 and SC 128 were evaluated at two locations, i.e. Mallawy, and Sakha Res. Stns. The experimental design was randomized complete block design (RCBD) with four replications. The plot size was one row, $6 \mathrm{~m}$ long and $0.8 \mathrm{~m}$ apart, with a distance of $25 \mathrm{~cm}$ between hills. All the recommended agronomic practices for maize production were applied at the proper time. Data were recorded for number of days to $50 \%$ silking, plant and ear height, ear length, ear diameter, no. of rows/ear, no. of kernels/row and grain yield ardab/ fad. adjusted at $15.5 \%$ moisture content and converted to $\operatorname{ardab~fed~}^{-1}(\mathrm{ardab}=140 \mathrm{~kg})$. The statistical analysis of RCBD was performed based on plot means from data collected on individual plants, according to Steel and Torrie (1980). Bartlett test was used to test the homogeneity of error variances for all studied traits and they found homogeneous. So, combined statistical analysis across locations was conducted. The combining ability analysis was done according Griffing's (1956) Method 4 Model 1 to estimate of general (GCA) and specific (SCA) combining ability variance and effects.

\section{RESULTS AND DISCUSSION Analysis of variance}

Combined analysis of variance for all studied traits is presented in Table (1). Highly significant differences were obtained among locations for all studied traits. Significant differences were also found among genotypes, indicating a large amount of variability among genotypes for all studied traits. General (GCA) and specific (SCA) combining ability mean squares were significant for all traits, indicating that both additive and non-additive gene effects were important in the inheritance of these traits. The magnitude of GCA mean squares was greater than that for SCA for all the studied traits, indicating that additive gene effects were predominant in the inheritance of these traits. The interaction between genotypes and locations was significant for all the studied traits, this could be interpreted that genotypes were inconsistent over location. Significant interaction of general and specific combining ability with locations were obtained for all studied traits, except for ear diameter for GCA X Loc and SCAx Loc, indicating that the magnitude of all types of gene action fluctuated from one location to another. The magnitude of GCAxLoc mean squares was greater than that for SCAxLoc. for all the studied traits, except for days to $50 \%$ silking and ear diameter indicating that additive gene action was more affected by the environment than non-additive of these traits. The significant interaction of additive gene effects with locations for these traits indicated that, it would not be effective to make selection on the basis of evaluation in a single environment and more environments are required.

Similar findings were found by El-Itriby et al (1990), Gado et al (2000), Al-Naggar et al (2002), Alamine et al (2006) and Sedhom et al (2007) who indicated the relative importance of GCA in controlling the inheritance of yield and some agronomic attributes in maize. However, Salama et al. (1995), Sadek et al. (2001), Singh and Roy (2007) and Abdallah and Hassan (2009), reported that the non-additive type of gene action appeared to be more important in the inheritance of yield and other agronomic traits.

\section{Mean performance}

Mean performance of the tested 36 single crosses, along with the two commercial check hybrids, SC 10 and SC 128 for eight studied traits are presented in Table (2). No significant differences were observed among the two check hybrids for grain yield and its components, while for morphological traits, number of days to $50 \%$ silking and plant and ear heights, SC 128 
had earlier flowering, shorter and lower ear heights than SC 10. The mean values of number of days to $50 \%$ silking ranged from 55.75 days for $\mathrm{P} 1 \mathrm{X} P 8$ to 60.75 days for $\mathrm{P} 3$ 


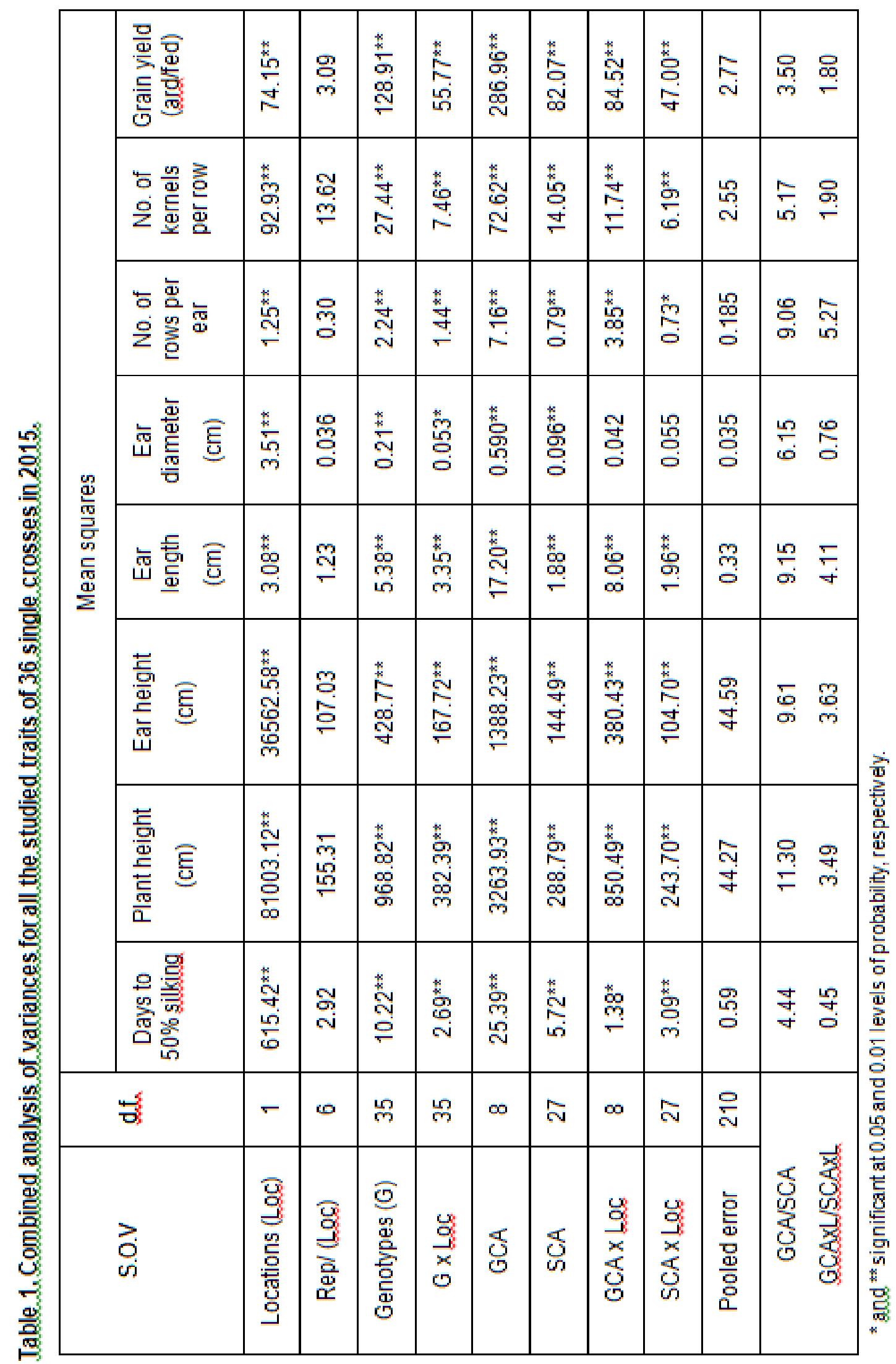


Table 2. Mean performance for studied traits of 36 ingle crosses combined across the two locations, in 2015.

\begin{tabular}{|c|c|c|c|c|c|c|c|c|}
\hline Crosses & $\begin{array}{l}\text { Days } \\
\text { to } 50 \% \\
\text { silking }\end{array}$ & $\begin{array}{c}\text { Plant } \\
\text { height } \\
(\mathrm{cm})\end{array}$ & $\begin{array}{c}\text { Ear } \\
\text { height } \\
(\mathrm{cm})\end{array}$ & $\begin{array}{l}\text { Ear } \\
\text { length } \\
(\mathrm{cm})\end{array}$ & $\begin{array}{c}\text { Ear } \\
\text { diameter } \\
(\mathrm{cm})\end{array}$ & $\begin{array}{c}\text { No. of } \\
\text { rows } \\
\text { per } \\
\text { ear }\end{array}$ & $\begin{array}{l}\text { No. of } \\
\text { kernels } \\
\text { per row }\end{array}$ & $\begin{array}{c}\text { Grain } \\
\text { yield } \\
\text { (ard/fed) }\end{array}$ \\
\hline P1 X P2 & 59.25 & 225.00 & 122.00 & 18.07 & 4.92 & 14.22 & 36.47 & 20.40 \\
\hline $\mathrm{P} 1 \times \mathrm{P} 3$ & 58.12 & 243.50 & 137.50 & 18.72 & 5.30 & 13.88 & 37.85 & 29.04 \\
\hline $\mathrm{P} 1 \times \mathrm{P} 4$ & 56.37 & 246.50 & 137.87 & 19.87 & 5.03 & 13.80 & 37.25 & 31.11 \\
\hline P1X P5 & 56.87 & 248.50 & 137.50 & 19.27 & 5.05 & 13.52 & 36.27 & 30.68 \\
\hline $\mathrm{P} 1 \times \mathrm{P} 6$ & 58.37 & 238.87 & 130.37 & 20.37 & 5.20 & 14.60 & 38.52 & 32.59 \\
\hline $\mathrm{P} 1 \times \mathrm{P} 7$ & 56.50 & 245.12 & 135.12 & 18.70 & 4.95 & 13.85 & 37.97 & 26.94 \\
\hline $\mathrm{P} 1 \mathrm{X}$ P8 & 55.75 & 233.00 & 132.12 & 20.32 & 4.95 & 13.62 & 39.12 & 30.49 \\
\hline P1X P9 & 57.25 & 255.62 & 144.87 & 22.02 & 5.33 & 15.80 & 44.50 & 39.35 \\
\hline P2 X P3 & 59.12 & 255.25 & 142.87 & 21.82 & 5.05 & 15.15 & 43.77 & 36.28 \\
\hline $\mathrm{P} 2 \times \mathrm{P} 4$ & 57.50 & 246.62 & 136.87 & 20.27 & 5.10 & 14.95 & 37.62 & 31.44 \\
\hline P2 X P5 & 57.12 & 245.25 & 135.75 & 18.47 & 5.05 & 14.00 & 37.62 & 29.75 \\
\hline P2X P6 & 59.62 & 235.87 & 127.50 & 18.32 & 5.18 & 14.02 & 36.50 & 29.84 \\
\hline P2 X P7 & 57.62 & 247.37 & 135.50 & 21.07 & 5.18 & 15.65 & 42.42 & 35.00 \\
\hline $\mathrm{P} 2 \times \mathrm{P} 8$ & 57.37 & 226.87 & 123.37 & 19.72 & 4.85 & 14.00 & 39.67 & 29.02 \\
\hline P2X P9 & 57.75 & 252.62 & 141.50 & 22.18 & 5.03 & 14.80 & 39.95 & 35.63 \\
\hline P3 X P4 & 58.37 & 258.25 & 143.37 & 19.97 & 5.00 & 14.62 & 38.05 & 31.25 \\
\hline P3 X P5 & 58.87 & 257.87 & 138.12 & 20.02 & 4.92 & 13.80 & 40.95 & 28.95 \\
\hline P3 X P6 & 59.87 & 240.00 & 140.00 & 19.77 & 4.90 & 14.10 & 38.92 & 31.88 \\
\hline P3 X P7 & 58.75 & 254.50 & 137.50 & 19.50 & 4.85 & 13.88 & 39.92 & 26.77 \\
\hline P3 X P8 & 58.00 & 246.87 & 136.62 & 19.75 & 4.85 & 13.30 & 40.15 & 26.08 \\
\hline P3 X P9 & 60.75 & 270.75 & 151.75 & 23.70 & 5.08 & 14.75 & 43.40 & 37.35 \\
\hline P4 X P5 & 57.87 & 243.75 & 126.50 & 19.35 & 4.90 & 12.85 & 36.98 & 26.84 \\
\hline P4 X P6 & 60.62 & 243.87 & 132.62 & 18.20 & 4.80 & 13.62 & 35.35 & 24.48 \\
\hline P4 X P7 & 57.75 & 244.62 & 133.75 & 20.02 & 4.92 & 13.33 & 40.70 & 30.73 \\
\hline P4 X P8 & 59.00 & 231.62 & 127.12 & 19.27 & 4.77 & 13.95 & 37.47 & 25.79 \\
\hline P4 X P9 & 58.25 & 255.37 & 140.62 & 21.45 & 4.90 & 13.20 & 39.67 & 34.00 \\
\hline P5 X P6 & 59.50 & 234.62 & 125.00 & 18.10 & 4.75 & 13.48 & 37.08 & 26.69 \\
\hline P5 X P7 & 56.87 & 243.25 & 125.87 & 18.82 & 4.75 & 13.12 & 38.73 & 27.20 \\
\hline P5 X P8 & 58.37 & 234.50 & 127.37 & 18.37 & 4.92 & 12.82 & 37.20 & 25.86 \\
\hline P5 X P9 & 58.75 & 245.87 & 133.37 & 21.08 & 4.95 & 13.58 & 42.85 & 32.89 \\
\hline P6 X P7 & 58.62 & 244.25 & 134.87 & 19.37 & 4.80 & 13.65 & 40.37 & 27.84 \\
\hline $\mathrm{P6} \times \mathrm{P} 8$ & 57.87 & 222.87 & 121.00 & 18.60 & 4.78 & 13.45 & 37.97 & 27.29 \\
\hline P6 X P9 & 59.37 & 251.50 & 142.00 & 22.30 & 4.95 & 14.50 & 40.57 & 35.35 \\
\hline P7 X P8 & 56.50 & 236.75 & 127.37 & 20.27 & 4.70 & 12.80 & 38.70 & 30.96 \\
\hline P7 X P9 & 59.25 & 254.62 & 139.62 & 21.62 & 4.90 & 13.60 & 42.00 & 32.36 \\
\hline P8 X P9 & 58.62 & 252.75 & 137.75 & 22.78 & 4.87 & 13.80 & 41.20 & 35.31 \\
\hline Check & 62.25 & 290.62 & 172.75 & 20.50 & 4.65 & 12.80 & 41.82 & 35.36 \\
\hline $\begin{array}{l}\text { SC10 } \\
\text { SC128 }\end{array}$ & 61.50 & 267.00 & 159.37 & 20.02 & 4.80 & 13.40 & 40.67 & 36.52 \\
\hline LSD 0.05 & 0.78 & 6.66 & 6.70 & 0.58 & 0.18 & 0.42 & 1.58 & 1.67 \\
\hline
\end{tabular}


$X$ P9. In general, all crosses were earlier than the earliest commercial check hybrid SC128 (61.50 days). For plant and ear heights, the shortest plant height $(222.87$ $\mathrm{cm}$ ) and lowest ear height (122.00) were obtained from the two crosses P6X P8 and P1 X P2, respectively. Whereas, the tallest plants $(270.75 \mathrm{~cm})$ and the highest ear placement $(151.75 \mathrm{~cm})$ were obtained from the crosses P3 $\times$ P4 and P3 $\times$ P9, respectively. All of $F_{1}$ crosses differ significantly from SC 128 for studied traits. The mean values of ear length ranged from $18.07 \mathrm{~cm}$ for $\mathrm{P} 1 \times \mathrm{P} 2$ to $23.70 \mathrm{~cm}$ for $\mathrm{P} 3 \mathrm{X}$ P9. Ten crosses i.e. $\mathrm{P} 1 \times \mathrm{P} 4$ and $\mathrm{P} 1 \times \mathrm{P} 7$ differ significantly from the check hybrid SC 10 for this trait. Regarding ear diameter, the mean values ranged from $4.70 \mathrm{~cm}$ for the cross P7 X P8 to $5.33 \mathrm{~cm}$ for P1 X P9. Out of the 36 crosses, 13 crosses differ significantly from the check hybrid SC 128. The mean values for number of rows per ear ranged from 12.80 rows for $\mathrm{P} 7 \times \mathrm{X} 8$ to 15.80 rows for $P 1 X P 9$. For this trait, 18 crosses, P1 X P2 surpassed significantly the check hybrid SC 128. Regarding number of kernels per row, the mean values ranged from 35.35 kernels for P4 X P6 to 44.50 kernels for $\mathrm{P} 1 \mathrm{X} P 9$. Out of the 36 crosses, 3 crosses i.e., $\mathrm{P} 1 \times \mathrm{P} 9, \mathrm{P} 2 \times \mathrm{P} 3$ and $\mathrm{P} 3 \times \mathrm{P} 9$ differ significantly from the check hybrid $\mathrm{SC}$ 128.

With respect to grain yield, the mean values ranged from 20.40 ard fad $^{-1}$ for $P 1 X$ $\mathrm{P} 2$ to $39.35 \mathrm{ard} \mathrm{fad}^{-1}$ for P1 X P9. One cross i.e. P1X P9 significantly out-yielded the check hybrid SC128, whereas, two crosses i.e. P1 X P9 and P3 X P9 significantly out-yielded the check hybrid SC 10 .

\section{General combining ability effects}

The estimates of GCA effects (gi) of the parental inbred lines for the studied traits are presented in Table 3. Negative values of GCA effects would be of interest for earliness, shortness and lower ear placement traits; the positive effects were considered favorable for grain yield and its components. The best GCA effects for days to $50 \%$ silking, were inbred lines that showed significant negative estimate of GCA effects P1 (-0.940), P7 (-0.476) and P8 $(-0.655)$ which can be considered the best combiner for earliness in the studied lines. With respect to plant height, negative significant GCA effects were obtained from the inbred lines P1, P2, P5, P6 and P8 ($3.250,-3.857, \quad-2.850$ and -10.143 . Significant and negative GCA effects were detected for lines P5 (-4.528), P6 (-3.796) and P8 (-6.009) for ear height. So, these three parents P5, P6 and P8 lines are characterized by additive genes for shorter plants and low ear placement. On the other hand, inbred lines P3 and P9 exhibited significant positive GCA effects towards tallness and high ear placement.

With respect to grain yield and its component, comparing GCA effects of individual parents (Table 3 ) showed that the parental inbred lines P2, P3, P7 and P9 had the highest, positive and significant GCA effects for ear length $(0.0 .232,0.317,0.217$ and 1.085, respectively). Meanwhile, P1 and P2 lines had positive and significant GCA effects (0.161 and 0.136) for ear diameter. Parents P1, P2, P6 and P9 had positive and significant GCA effects $(0.302,0.402,0.309$ and 0.296 ) for number of rows per ear, while the parental lines P3, P7 and P9 exhibited the highest positive and significant GCA effects (1.279, 0.586 and 2.122, respectively) for number of kernels per row. The positive and significant estimates of GCA effects for these inbred lines indicated that these inbred lines possess favorable additive genes for these traits.

With respect to grain yield (ard/fed), significant and positive GCA effects were obtained by P2, P3 and P9 (0.611, 0.648 and 5.522, respectively), indicating that these lines possess favorable additive genes for yield which can be utilized in the hybrid breeding program. 


\begin{tabular}{|c|c|c|c|c|c|c|c|c|c|c|c|}
\hline 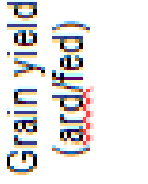 & $\underset{m}{m}$ & $\stackrel{\circ}{\circ}_{0}^{*}$ & 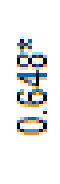 & 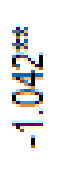 & $\frac{\text { 尃 }}{\frac{\mathrm{g}}{\mathrm{g}}}$ & 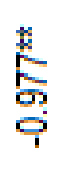 & $\begin{array}{l}\stackrel{*}{\leftarrow} \\
\stackrel{0}{0} \\
\stackrel{9}{0}\end{array}$ & 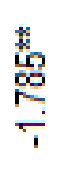 & 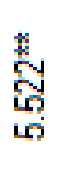 & $\begin{array}{l}\text { ঙ্ } \\
\text { ডু }\end{array}$ & $\begin{array}{l}\text { 告 } \\
0\end{array}$ \\
\hline 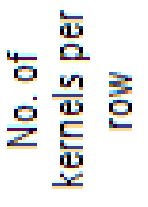 & $\frac{\text { 关 }}{8}$ & $\underset{\square}{\stackrel{+}{0}}$ & 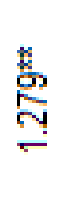 & 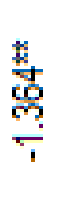 & $\begin{array}{l}\text { 응 } \\
\text { 웅 }\end{array}$ & \begin{tabular}{l} 
今. \\
o \\
\multirow{2}{*}{} \\
0
\end{tabular} & $\begin{array}{l}\text { 承 } \\
\text { 吕 } \\
0\end{array}$ & $\frac{3}{0}$ & 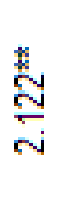 & 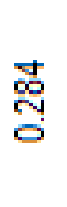 & 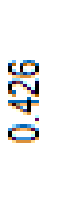 \\
\hline 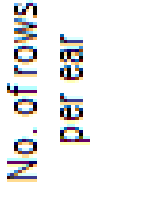 & ণั & 尊 & 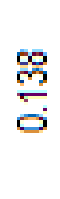 & $\frac{\stackrel{*}{c}}{\stackrel{\infty}{\infty}}$ & 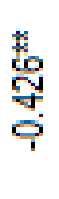 & 卷 & 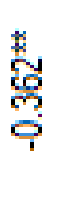 & 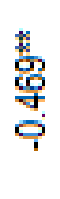 & 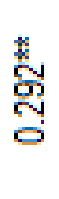 & $\begin{array}{l}\stackrel{\circ}{\circ} \\
\stackrel{\circ}{\circ}\end{array}$ & $\frac{ \pm}{5}$ \\
\hline 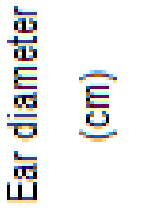 & $\frac{\frac{1}{6}}{6}$ & $\frac{\text { 恖 }}{\stackrel{0}{\circ}}$ & ঠ్ & $\begin{array}{l}\text { 용 } \\
\text { ب̣ }\end{array}$ & 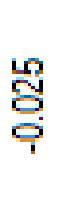 & ช్ & $\frac{\text { 울 }}{\frac{0}{0}}$ & 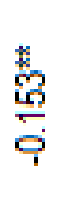 & 号 & ஜֶ. & 녕 \\
\hline $\begin{array}{l}\text { 䓌 } \\
\text { 㤐 } \\
\text { 莺 }\end{array}$ & 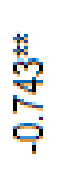 & సેّ & 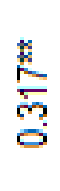 & $\frac{\mathscr{m}}{\stackrel{0}{\circ}}$ & 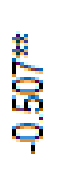 & 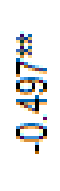 & $\frac{\stackrel{*}{\kappa}}{\stackrel{N}{\sigma}}$ & 岁 & $\begin{array}{l}\text { 巻 } \\
\text { 总 } \\
\stackrel{8}{\circ}\end{array}$ & $\frac{8}{\circ}$ & $\frac{\pi}{5}$ \\
\hline 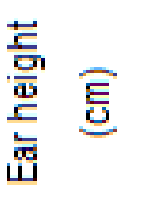 & 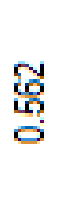 & 㟧 & 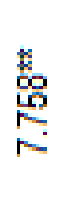 & 胥 & 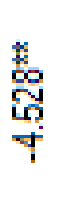 & 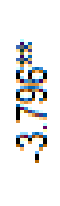 & $\frac{9}{\frac{9}{0}}$ & $\begin{array}{l}\text { 卷 } \\
8 \\
8 \\
8 \\
0\end{array}$ & $\begin{array}{l}\stackrel{*}{*} \\
\stackrel{5}{\sigma} \\
\end{array}$ & 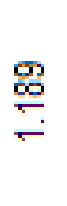 & 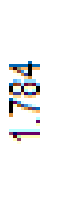 \\
\hline 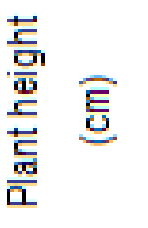 & $\begin{array}{l}\text { 章 } \\
\text { 号 } \\
\text { ry }\end{array}$ & 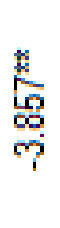 & 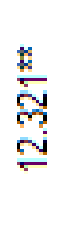 & $\stackrel{\substack{\infty \\
\hdashline}}{\longrightarrow}$ & 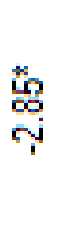 & 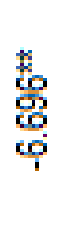 & ণ্ণ & $\frac{\stackrel{4}{9}}{\frac{9}{8}}$ & 密 & $\stackrel{\text { 용 }}{=}$ & 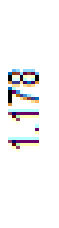 \\
\hline 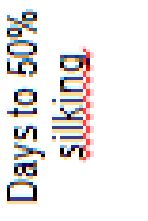 & 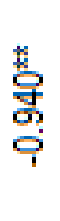 & $\frac{N}{\stackrel{0}{0}}$ & 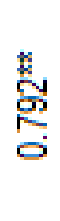 & 웅 & $\frac{\sigma}{\frac{0}{9}}$ & $\begin{array}{l}\stackrel{1}{*} \\
\stackrel{5}{\circ}\end{array}$ & $\begin{array}{l}\text { 承 } \\
\text { 守 } \\
\text { ơ }\end{array}$ & 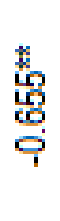 & 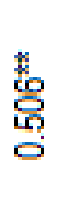 & $\stackrel{\stackrel{m}{\circ}}{\circ}$ & 옹 \\
\hline 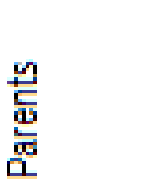 & $\bar{\alpha}$ & $\approx$ & $\widetilde{\alpha}$ & व & $\stackrel{2}{2}$ & ஜ̊ & $\underline{\alpha}$ & $\stackrel{\circ}{\circ}$ & ฉ̊ & 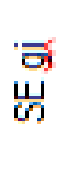 & $\begin{array}{l}\text { वै } \\
\text { के } \\
\text { ऊँ }\end{array}$ \\
\hline
\end{tabular}


In these connections inbred line P8 possess favorable genes for earliness, short plant and low ear placement, P1 and P2 for ear diameter and row number, P3, P7 and $\mathrm{P} 9$ for ear length and kernel number, P3 and P9 for grain yield, ear length and kernel number.

\section{Specific combining ability effects}

Estimates of SCA effects for the $F_{1}$ generation of the studied traits are presented in Table (4). Negative and significant and or highly significant SCA effects for days to $50 \%$ silking were obtained in six crosses. The best cross combinations for earliness were $\mathrm{P} 1 \times \mathrm{P} 4, \mathrm{P} 1 \times \mathrm{P} 8, \mathrm{P} 2 \mathrm{X}$ $\mathrm{P} 5, \mathrm{P} 2 \times \mathrm{P} 9, \mathrm{P} 3 \times \mathrm{P} 4$ and $\mathrm{P} 6 \times \mathrm{P} 9$, indicating that these combinations could be useful in areas that require early maturing hybrids. Concerning plant and ear heights, cross (P1 $X$ P2) showed significant and negative SCA effects for plant and ear height, indicating that these cross involved inbreeds that are considered good combiners for shortness and lower ear placement. Meanwhile, two crosses P5 X P6 and P5 X P9 exhibited significant negative SCA effects for plant height. With respect to grain yield and its components, the study indicated that $(\mathrm{P} 1 \times \mathrm{P} 6, \mathrm{P} 3 \times \mathrm{P} 5, \mathrm{P} 4 \times \mathrm{P} 7$ and P5 X P9); (P2 X P7); (P1 X P6, P1 X $\mathrm{P} 9, \mathrm{P} 2 \times \mathrm{P} 9$ and $\mathrm{P} 3 \times \mathrm{P} 4) ;(\mathrm{P} 1 \times \mathrm{P} 6, \mathrm{P} 2 \mathrm{X}$ P3, P4 X P7, P5 X P9 and P6 X P7) crosses were the best cross combinations among all the studied hybrids for ear length, ear diameter, number of rows per ear and number of kernels per row respectively. Furthermore, the crosses P4 X P7, P1 X P5, $\mathrm{P} 1 \times \mathrm{P} 6, \mathrm{P} 1 \times \mathrm{P} 8, \mathrm{P} 1 \times \mathrm{P} 9, \mathrm{P} 2 \times \mathrm{P} 3, \mathrm{P} 2 \times$ $\mathrm{P} 7, \mathrm{P} 3 \times \mathrm{P} 6$ and $\mathrm{P} 7 \times \mathrm{P} 8$ exhibited the highest specific combining ability effects for grain yield. Out of these crosses there were three crosses P1 X P9, P2 X P3 and P2 XP7 gave the highest mean performance for grain yield (39.35, 36.28 and $35.00 \mathrm{ard} / \mathrm{fed}$, respectively). These crosses represented the parental combinations of (low $x$ high), (high $x$ high) and (high $x$ low) GCA effects. This suggests that either additive $x$ additive or additive $\mathrm{x}$ dominance genetic interactions were involved in these crosses. For grain yield, the superiority of these crosses may be due to complementary and duplicate type of gene interactions. Hence, these hybrids could be exploited successfully in the national hybrid breeding program. Similar findings were reported earlier by Nawar and EL-Hosary (1985), Soliman et al (2001), Sadek et al (2002), Gabr et al (2008) and Abdallah et al (2009).

The previous results imply that the three parental inbred lines $P_{2}, P_{3}$ and $P_{9}$ possess favorable alleles for grain yield and most of yield components and may be considered as promising inbred lines. Moreover, the promising cross $\mathrm{P}_{1} \times \mathrm{P}_{9}$ and, $\mathrm{P}_{3} \mathrm{XP}_{9}$ (39.35 and $37.35 \mathrm{ard} \mathrm{fad}^{-1}$ ), which yielded as much as the highest yielding check hybrid may be released as a commercial hybrid by the Maize Research Program after further testing and evaluation. 
Table 4. Estimates of Specific combining ability effects for studied traits of $\mathbf{3 6}$ single crosses combined across the two locations, in 2015.

\begin{tabular}{|c|c|c|c|c|c|c|c|c|}
\hline Crosses & $\begin{array}{c}\text { Days to } \\
50 \% \\
\text { silking } \\
\end{array}$ & $\begin{array}{c}\text { Plant } \\
\text { height } \\
(\mathrm{cm})\end{array}$ & $\begin{array}{c}\text { Ear } \\
\text { height } \\
(\mathrm{cm})\end{array}$ & $\begin{array}{c}\text { Ear } \\
\text { length } \\
(\mathrm{cm})\end{array}$ & $\begin{array}{c}\text { Ear } \\
\text { diameter } \\
(\mathrm{cm})\end{array}$ & $\begin{array}{c}\text { No. of } \\
\text { rows per } \\
\text { ear }\end{array}$ & $\begin{array}{c}\text { No. of } \\
\text { kernels } \\
\text { per row }\end{array}$ & $\begin{array}{c}\text { Grain } \\
\text { yield } \\
\text { (ard/fed) }\end{array}$ \\
\hline P1 X P2 & $2.227^{\star \star}$ & $-16.330^{* *}$ & $-11.638^{* *}$ & -0.029 & $-0.281^{* *}$ & -0.302 & 0.630 & $-10.220^{* *}$ \\
\hline $\mathrm{P} 1 \times \mathrm{P3}$ & 0.138 & \begin{tabular}{|l|}
-5.384 \\
\end{tabular} & \begin{tabular}{|l|}
-3.031 \\
\end{tabular} & -0.465 & 0.108 & $-0.463^{*}$ & -1.387 & $-1.614^{*}$ \\
\hline $\mathrm{P} 1 \times \mathrm{P} 4$ & $-0.808^{*}$ & 3.187 & 2.379 & 0.267 & -0.009 & -0.138 & 0.405 & $2.019^{* \star}$ \\
\hline $\mathrm{P} 1 \times \mathrm{P} 5$ & -0.200 & $9.937^{\star *}$ & $7.004^{*}$ & -0.340 & 0.079 & -0.074 & -0.573 & $2.663^{\star *}$ \\
\hline P1 X P6 & 0.102 & 0.384 & -0.853 & $0.749^{* *}$ & 0.162 & $0.440^{*}$ & $1.755^{*}$ & $3.555^{\star *}$ \\
\hline $\mathrm{P} 1 \times \mathrm{P} 7$ & -0.218 & 2.366 & 1.147 & -0.040 & -0.135 & 0.086 & -0.394 & $-2.458^{* \star}$ \\
\hline $\mathrm{P} 1 \times \mathrm{P} 8$ & $-0.790^{*}$ & 2.955 & 3.112 & 0.267 & -0.017 & -0.031 & 0.894 & $2.267^{\star \star}$ \\
\hline $\mathrm{P} 1 \times \mathrm{P9}$ & -0.451 & 2.884 & 1.879 & -0.408 & 0.094 & $0.483^{*}$ & -1.330 & $3.787^{* \star}$ \\
\hline $\mathrm{P} 2 \times \mathrm{P3}$ & 0.370 & 1.473 & 2.040 & 0.485 & -0.067 & -0.213 & $2.269^{\star \star}$ & $4.635^{\star \star}$ \\
\hline $\mathrm{P} 2 \times \mathrm{P} 4$ & -0.451 & 3.919 & 3.325 & 0.042 & 0.065 & -0.088 & 0.362 & 1.490 \\
\hline P2 X P5 & $-0.718^{*}$ & $7.294^{*}$ & $7.201^{*}$ & -0.115 & 0.104 & 0.176 & -0.091 & .748 \\
\hline P2X P6 & 0.084 & 1.741 & -1.781 & 0.124 & 0.161 & -0.259 & $-2.312^{\star *}$ & -0.179 \\
\hline $\mathrm{P} 2 \times \mathrm{P} 7$ & 0.138 & 5.223 & 3.468 & -0.115 & $0.190^{*}$ & -0.213 & -0.662 & $4.604^{\star *}$ \\
\hline $\mathrm{P} 2 \times \mathrm{P} 8$ & -0.683 & -3.812 & -3.067 & 0.367 & -0.067 & 0.244 & 1.302 & .191 \\
\hline P2X P9 & $-0.969^{*}$ & 0.491 & 0.451 & $-0.758^{* *}$ & -0.106 & $0.658^{* *}$ & $-1.498^{*}$ & -0.887 \\
\hline P3 X P4 & $-1.040^{\star \star}$ & -0.634 & 0.683 & \begin{tabular}{|l|}
-0.469 \\
\end{tabular} & -0.020 & $26^{\star \star}$ & $-1.580^{*}$ & 1.261 \\
\hline P3 X P5 & 0.067 & 3.741 & 0.433 & $0.849^{* \star}$ & -0.031 & 0.265 & 1.441 & -0.091 \\
\hline P3 X P6 & -0.504 & 2.187 & 1.575 & -0.287 & -0.049 & 0.079 & -0.280 & $11.825^{*}$ \\
\hline P3 X P7 & 0.299 & -3.830 & -3.674 & $-0.650^{* *}$ & -0.020 & 0.275 & -1.280 & $-3.649^{* *}$ \\
\hline P3 X P8 & & & 0.415 & & 0.0 & & 134 & \\
\hline P3 X P9 & $0.942^{*}$ & 2.437 & 1.558 & 0.431 & 0.058 & -0.377 & 684 & 0.794 \\
\hline P4 X P5 & -0.129 & 0.062 & -3.906 & 0.131 & 0.001 & -0.135 & -0.391 & -0.507 \\
\hline $\mathrm{P} 4 \times \mathrm{P} 6$ & $1.424^{\star *}$ & 4.009 & 1.486 & $-0.779^{\star *}$ & -0.092 & 0.179 & -0.837 & $-3.634^{\star *}$ \\
\hline $\mathrm{P} 4 \times \mathrm{P} 7$ & 0.102 & -3.259 & -0.138 & $0.781^{* *}$ & 0.112 & 0.050 & $2.237^{\star \star}$ & $1.996^{*}$ \\
\hline $\mathrm{P} 4 \times \mathrm{P} 8$ & $1.281^{* *}$ & -4.795 & -1.549 & -0.112 & 0.004 & 0.033 & 0.102 & $-1.761^{*}$ \\
\hline P4 X P9 & -0.379 & -2.491 & -2.281 & 0.138 & -0.059 & $-0.527^{* *}$ & -0.298 & -0.865 \\
\hline $\mathrm{P} 5 \times \mathrm{P} 6$ & 0.406 & $-10.491^{* *}$ & -5.388 & -0.512 & -0.152 & -0.231 & -0.616 & -0.718 \\
\hline P5 X P7 & -0.665 & \begin{tabular}{|l|}
-3.634 \\
\end{tabular} & -4.263 & -0.126 & -0.074 & 0.090 & -0.716 & -0.419 \\
\hline P5 X P8 & $1.013^{* *}$ & 2.830 & 3.450 & $-0.519^{*}$ & 0.094 & 0.022 & -1.052 & -0.992 \\
\hline P5 X P9 & 0.227 & $-9.741^{* *}$ & -4.531 & $0.631^{*}$ & -0.020 & -0.113 & $1.998^{*}$ & -1.522 \\
\hline P6 X P7 & 0.013 & 4.937 & 5.254 & 0.288 & -0.017 & -0.195 & $1.487^{*}$ & -0.952 \\
\hline P6 X P8 & -0.683 & -4.973 & -3.656 & 0.320 & 0.001 & -0.088 & -0.598 & -0.331 \\
\hline P6 X P9 & $-0.843^{*}$ & 2.205 & 3.362 & 0.095 & -0.013 & 0.076 & 1.402 & 0.435 \\
\hline P7 X P8 & -0.504 & 0.884 & -0.031 & -0.219 & -0.070 & 0.058 & -0.248 & $2.975^{* \star}$ \\
\hline P7 X P9 & $0.835^{*}$ & -2.687 & -1.763 & 0.082 & 0.015 & -0.153 & -0.423 & $-2.935^{\star *}$ \\
\hline P8 X P9 & 0.638 & $6.902^{*}$ & 1.325 & -0.212 & 0.033 & -0.045 & -0.534 & 1.194 \\
\hline SE Sij & 0.356 & & 3.091 & 0.265 & 0.086 & 0.199 & 0.739 & 0.770 \\
\hline $\begin{array}{c}\text { SE(sij- } \\
\text { sik) }\end{array}$ & 0.504 & 4.355 & 4.371 & 0.376 & 0.122 & 0.281 & 1.045 & 1.089 \\
\hline
\end{tabular}

${ }^{*}$ and ${ }^{* *}$ significant at 0.05 and 0.01 levels of probability, respectively. 


\section{REFERENCES}

Abdallah, T. A. E., Afaf A. I. Gabr and A.A. El Khishen (2009). Combining ability in line $x$ tester crosses of maize (Zea mays L.). Annals of Agric. Sci. Moshtohor. 47(1): 11-20.

Abdallah, T.A.E. and M.M. Hassan (2009). Combining ability analysis for grain yield and some agronomic traits in maize. Egypt. J. App. Sci., 24(11):164-174.

Abd El-Aty, M.S. and Y.S. Katta (2002). Estimation of heterosis and combining ability for yield and other agronomic traits in maize hybrids (Zea mays L.). J. Agric. Sci., Mansoura Univ., 27(8): 5137-5146.

Abd El-Moula, M.A. (2005). Combining ability for grain yield and other traits in some newly developed inbred lines of yellow maize. Egypt. J. Plant Breed., 9(2): 53-70.

Alamine, A., M.C. Wali, P.M. Salimath and R.C. Jadeesha (2006). Combining ability and heterosis for grain yield and ear characters in maize. Karanataka J. Agric. Sci. 19:13-16.

Al-Naggar, A.M., M. S. Radwan and M. M. M. Atta (2002). Analysis of diallel crosses among ten maize populations differing in drought tolerance. Egypt. J. Plant Breed., 6:179-198.

Beck, D.L., S.K. Vassal and J. Crossa (1991). Heterosis and combining ability among subtropical and temperate intermediate maturity maize germplasm. Crop Sci., 31: 68-73.

Derera, J., P. Tongoona, K.V. Pixly, B. Vivek, M.D. Laing and N.C. van Rij (2008). Gene action controlling gray leaf spot resistance in southern African maize germplasm. Crop Sci., 48: 93-98.

El-Hosary, A.A., A.A. Abdel-Sattar and M.H. Motawea (1999). Heterosis and combining ability of seven inbred lines of maize in diallel crosses over two years. Minufiya, J. Agric. Res., 24(1): 65-84.

El-Itriby, H.A., M.M. Ragheb, H.Y.ElSherbieny and M.A. Shalaby (1990). Estimates of combining ability of maize inbred lines in top crosses and it's interaction with environments. Egypt. J. Ap. Sci. 5(8): 354-370.

El-Shamarka, Sh.A. (1995). Estimation of heterotic and combining ability effects for some quantitative characters in maize under two nitrogen levels. Minufiya, J. Agric. Res., 20(21): 441-462.

Gabr, Afaf A. I., M. E. M. Abd E-Azeem and T. A. E. Abdallah (2008). Combining ability analysis of grain yield and some agronomic traits of nine maize inbred lines. Egypt. J. Ap. Sci. 23(12B): 520529.

Gado, H.E., M. S. M. Soliman and M.A.K. Shalaby (2000). Combining ability analysis of white maize (Zea mays L.) inbred lines. J. Agric. Sci. Mansoura Univ. 25:3719-3729.

Griffing, B. (1956). Concept of general and specific combining ability in relation to diallel crossing system. Aust. J. Biol. Sci. 9:463-493.

Ibrahim, Kh.A.M., M.A. Abd El-Moula and M.E.M. Abd El-Azeem (2010). Combining ability analysis of some yellow maize (Zea mays L.) inbred lines. Egypt. J. Agric. Res., 88(1): 33-50.

Matzinger, D.F., G.F. Spraque and C.C. Cockerham (1959). Diallel crosses of maize in experiments reported over locations and years. Agron. J., 51: 346350.

Nawar, A. A. and A. A. El-Hosary (1985). A comparison between two experimental diallel cross designs. Minoufiya J. Agric. Res. 10: 2029-203

Sadek, S.E., M.S.M. Soliman and A.A. Barakat (2001).Evaluation of newly developed maize lines using commercial inbred testers. Egypt. J. Appl. Sci.16:406425.

Sadek, S. E., M.S.M. Soliman, A. A. Barakat and K. I Khalifa (2002). Topcross analysis for selecting maize lines in the early self generations. Minoufiya J. Agric. Res., 27:197-213.

Salama, F.A., Sh.F. Abo El.Saad and M.M. Ragheb (1995). Evaluation of maize (Zea mays L.) top crosses for grain yield and 
other agronomic traits under different environmental conditions. J.Agric. Sci. Mansoura Univ. 20(1): 127-140.

Sedhom, A.S., M.EL.M. El-Badawy, A.M. Morsy and A.A.A. E-Hosary. (2007). Diallel analysis and relationship between molecular polymorphisms and yellow maize performance. J. Agric. Sci. Benha Univ. 45:1-20.

Sibiya, J., P. Tongoona, J. Derera and N. van Rij (2011). Genetic analysis and genotype $x$ environment (GxE) for grey leaf spot disease resistance in elite African maize (Zea mays L.) germplasm. Euphytica, 179 (1): 312-325.

Singh, P.k. and A.K. Roy. (2007). Diallel analysis of inbred lines in maize (Zea maiys L.). Intl. J. Agric. Sci. 3(1):213-216.

Soliman, M. S. M., A. A. Mahmoud, Afaf A. I. Gabr and F. H. S Soliman. (2001).
Utilization of narrow base testers for evaluating combining ability of newly developed yellow maize inbred lines (Zea mays L.). Egypt. J. Plant Breed. 5:61-76.

Sprague, G.F. and L.A. Tatum (1942). General versus specific combining ability in single crosses of corn. J. Amer. Soc. Agron. 34: 923-932.

Steel, R. G. D. and J.H Torrie,. (1980). Principles and Procedures of Statistics: A biometrical approach $2^{\text {nd }}$. Mc Graw Hill Book Co. Inc., N. Y., USA.

Vivek, B.S., O. Odongo, J. Njuguna, J. Imanywoha, G. Bigirwa, A. Diallo and K. Pixley (2010). Diallel analysis of grain yield and resistance to seven diseases of 12 African maize (Zea mays L.) inbred lines. Euphytica, 172: 329-340. 
القدرة على التآلف لتسعة سلالات ذرة شامية بيضاء الحبوب لصفة المحصول ويعض الصفات الزراعية

أشرف كمال مصطفى ، محمود عبد الفتاح عبدالوهاب مصطفى

قسم بحوث الذرة الثامية- معهد المحاصيل الحقلية - مركز البحوث الزراعية

الملخص العربى

تم إستخدام تحليل القدرة على الآئتلاف لصفة الدحصول ومكوناته ولبعض الصفات الزراعية الأخرى مثل عدد الأيام من

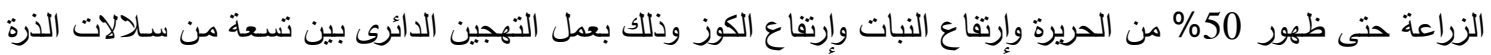

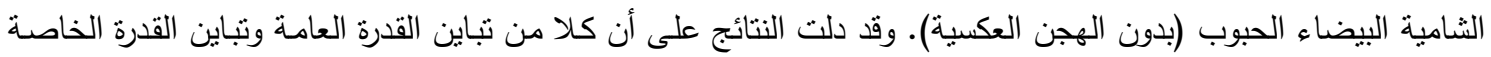
على الإئتلاف عالية المعنوية لكل الصفات تحت الدراسة وأن كلا من الفعل المضيف وغير المضيف يلعبان دورا هاما فى الئ

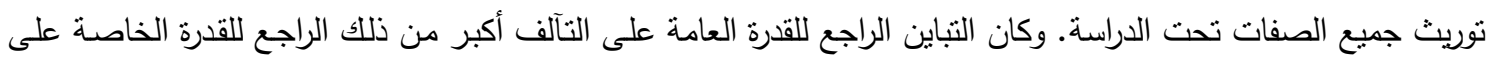
التآلف لجميع الصفات مدا يدل على أن التباين الوراثى المضيف هو الأكثر أهمية فى وراثة هذه الصفات. وقد أظهرت السلالات P ت تأثيرات عالية المعنوية وموجبة للقدرة العامـة على الإيتتلاف لصفة المحصول وبعض مكوناته، بينما

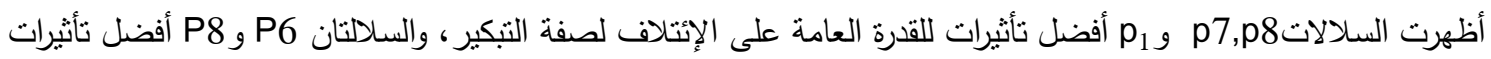

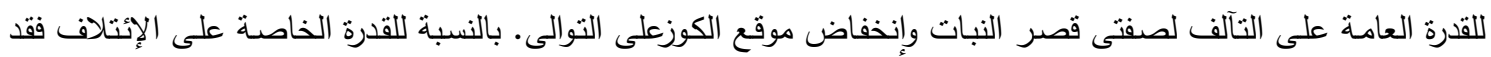

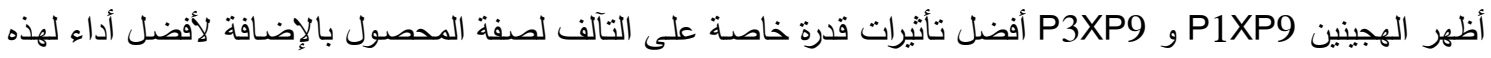
الصفات. لذللك فإنه يمكن إستغلال هذه السلالات والهجن المتفوقة في برنامج الثربية للتبكير وإنتاج هجن عالية المحصول

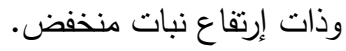


